\title{
Indonesian University Students' Perception and Expectation towards ICT Use in Learning English as a Foreign Language
}

\author{
Tubagus Zam Zam Al Arif \\ Universitas Jambi, Indonesia \\ e-mail:zamzam@unja.ac.id
}

\begin{abstract}
:
This study aims to know the use of ICT frequency and purposes among EFL university students. It is also examines the students' perception and expectation towards ICT use in learning English as a foreign language. This research applied quantitative approach with a survey research design. The data were collected from a survey which involved 337 students who were selected using stratified random sampling technique from 13 faculties of a state university in Jambi, Indonesia. The instrument used in collecting the data was a questioner adapted from Tri and Nguyen (2014). Data collected were analyzed by using SPSS 23 in form of descriptive quantitative. The findings indicated that the students spent more time in using ICT for general purposes than English learning purposes. On the other hand, they showed positive attitudes towards the use of ICT in learning English. The students perceive that ICT has the important role in improving their English language skills, and they expected that the teachers use ICT more frequently in teaching and learning process. Furthermore, they expected that campus can provide sufficient equipment and ICT access in each classroom in order to make the learning process become effective.

Keywords: English as Foreign Language (EFL), Information and Communication Technology (ICT), Students' Expectation, Students' Perception
\end{abstract}

\section{Introduction}

It's a fact that technological advances have had such a huge impact on the field of education especially in learning English as a foreign language. The use of ICT in learning English can assist students in improving their language skills (Khaloufi \& Laabidi, 2017), aside from that, ICT utilization may empower and motivate learners in English language learning. ICT utilization can provide opportunities for collaboration and interaction in learning process, and also the instruction needs to be scaffolded for learners to benefit from such opportunities (Murray, 2005).

Information and communication Technology (ICT) is more commonly used in language learning and teaching in the last decade. ICT refers to the computers-based technologies and internet-based technologies which is used for creating, storing, displaying and sharing 
information. ICT provides a context for human-human and human machine communication, and it provides a context for information production, display, delivery, and sharing. In the context of EFL, ICT can provide English language learners with opportunities for interaction to native speakers through ICT tools such as e-mail, social networking like facebook (Annamalai, 2017), and video-based communication like skype.

ICT has been used in the classrooms from elementary school to higher education. ICT utilization provides the opportunity for students to find out the learning material and practice their English language skills (Anas \& Musdariah, 2018). Moreover, ICT can be used to attract and grow students' interest and their positive attitudes in learning English, and it is also expected that ICT should be used more frequently in the classroom in order to maximize language teaching and learning (Tri \& Nguyen, 2014). The use of ICT can provide students the opportunities to practice their English in real context of language use (Kramsch \& Thorne, 2002). The learners can use skype to interact to native speaker (Dalton, 2011). In addition, the teachers can use video resources in the classroom to enhance English language learning (Boutonglang \& Flores, 2011).

The use of ICT can help English language learners to improve their English language skills in English language teaching process (Fauzan \& Pimada, 2018). The university students are more interested in English language learning when the teachers using ICT in English language teaching process (Chouit, Abdelhamid, \& Laabidi, 2017). The effects of technology use in the classrooms makes the students active and enjoy the classrooms activities. The integration of ICT also increases students' motivation in EFL context (Ilter, 2009).

In Indonesia especially in English Department of a state university in Jambi, the students perceive that ICT is useful to be used in English language learning. They used ICT only for projector as a media in teaching and learning process (Oktalia, Ngadiso, \& Supriyadi, 2018). This is fact for the students of English Department at Jambi University. The Students used ICT for searching information given by the lecturer, and the lecturer used the ICT for presenting material and as a media in teaching. Therefore, the use of ICT needs to be investigated further to know the students perception and expectation towards the use of ICT in English language learning inside and outside the classroom.

Consequently, this study aims to find out the role of ICT in learning English as a foreign language. This study attempts to answer the questions; 1 ). What is the frequency of the use of ICT for general purposes and English language learning purposes? 2). What activities do the students use ICT for general purposes? 3). What activities do the students use ICT for English language learning purposes? 4). What are the students' perceptions of ICT use in English language learning? 5). What are the students' expectations of ICT use in English language learning?

\section{Literature Review}

\subsection{ICT Definition}

Information and communication technology (ICT) is defined by UNESCO as forms of technology used for creating, displaying, storing, manipulating, and exchanging information (Meleisea, 2007). ICT refers to computer-based technologies and networks-based technologies that provide a context for information production, delivery, and sharing (Murray, 2005). In 
general, ICT refers to the computers, hardware and software, smartphones, gadgets, networks, internet, website, e-mail, television, radio and other computer-based technologies. Information and Communication Technology (ICT) has brought profound changes to all aspects of our lives, and it has an important role to play in education. The ICT utilization in the last decade has made a high contribution in English language learning.

According to Kennewell (2004), ICT covers all aspects of computers, networks (internet) and certain other devices with information storage and processing capacity such as TV, mobile phones, and automatic control devices. In this research, ICT refers to computer-based technologies and internet based-technologies such as desktop, laptops, smartphones, gadget, email, social networking, website, and software related to English language learning and teaching (Davies \& Hewer, 2009).

\subsection{ICT for ELT}

Since the first appearance of ICT integration in education in the last decades, a substantial investment has been made in ICT facilities and training in Indonesia universities. In Indonesia, as in other countries, the use of ICT in education concentrates on the potential contribution of ICT on teaching and learning process. ICT makes teaching and learning activities more active, and it has the contribution to increase the students' engagement. ICT use in English language teaching makes the students tend to have a positive perception, and positive attitudes towards ICT integration in the classroom (Boutonglang \& Flores, 2011; Harris, 2011).

Using ICT in the classrooms has a great potential for English language leaning. It can offer active learning process and motivate the learners. The technological equipment such as TV, Laptop, Projector, and interactive video will affect the learners' attitude in English language learning process. The learners can develop their language skills and give the sense of freedom and encouragement using kinds of technological equipment (Krista \& Jay, 2001).

\subsection{Benefit of ICT use Integration in ELT}

Many claims are made about the benefits of ICT integration in ELT. Technological equipment including the internet makes the process of teaching and learning easier and faster, but also to increase the students' engagement and motivation (Fatiha, Sliman, Mustapha, \& Yahia, 2014; Ilter, 2009). The use of ICT brings many advantages to learners. The learners may have opportunity to search for a variety of materials. The advantages of using ICT in education such as Social Networking Services (SNS) were social interaction (peer discussion and platform to interact between students and supervisors or lecturers) and learning motivation and experience supports (Habibi et al., 2018).

The implication of ICT integration in ELT can support both teachers and learners. Technology devices have been viewed and realized as significant and useful tools especially in English language teaching. ICT use in ELT help the students to increase their attitudes in learning English (Idowu \& Gbadebo, 2017; Sabti \& Chaichan, 2014). Using ICT in the classroom may bring positive attitudes for both teachers and learners (Benghalem, 2015).

Moreover, others research conducted to support the benefits of ICT integration in ELT often relies on introducing the learners to the new devices, software, and websites for learning and practicing English language.(Zhang, Song, \& Burston, 2011). There are so many kinds of devices, software, and websites that can be accessed by the learners to improve their English skills. The 
internet-based technologies allows the learners to access to the authentic materials to make them enjoy the English language learning (Shevchenko, 2018). These devices provide the learners in order to interact, share, and experience the learning in authentic environments.

\subsection{Previous Studies of ICT Integration in ELT}

A number of related studies of ICT use in English language teaching have been conducted in the worldwide. For instance, in the U.S (Foti \& Mendez, 2014; Johri, Teo, Lo, Dufour, \& Schram, 2014), or in Australia (Manakil \& George, 2017; Vaughan, 2011), which, however did not address in EFL context.

In EFL context, they tend to focus on investigating the students attitudes and barriers (Sabti \& Chaichan, 2014), this study involves 30 Saudi Arabia students of a high school in Kuala Lumpur, Malaysia. The analysis of the study revealed gender differences in attitudes towards the use of technologies in learning English. Female students showed high and positive attitudes than males. Other related studies was conducted to investigate ICT use in learning and using English in EFL university students (Alfarwan, 2019). This study involves 138 Saudi English and business students at a Saudi university through a survey. The findings indicated that smartphone has the greatest potential for further exploitation in relation to English, followed by the laptop and tablet.

The last related study was conducted by (Tri \& Nguyen, 2014), it undertook 149 EFL students at a university in Vietnam who responded to the questionnaire survey. The findings indicated that the learners spent more time using ICT for private purposes than for English learning purposes. Specifically, $88,4 \%$ of them using ICT for general purposes, and only $12.6 \%$ of them used ICT for English learning purposes.

\section{Research Methodology}

The current study used the quantitative approach with a survey design to investigate the frequency of ICT use for general purposes and English language learning purposes. In addition, it explores the students' perception and expectation towards the use of ICT in English language learning. The data were collected using a questionnaire adapted from Tri and Nguyen (2014). The questionnaire was administered randomly to 337 students from 13 faculties who had been taken English language course at Jambi University. The students had normally studied English for three years at secondary school, three years at high school and taken further English course at university. The data analyzed by using SPSS 23 in descriptive quantitative of students' perception, students' expectation, students' activities of ICT use for general purposes and for English language learning purposes.

\subsection{Population and Sample}

This study conducted at Jambi University. The population of this study is the students of the first year who had been taken English language course at Jambi University in academic year 2018 - 2019. The students had normally studied English for three years at secondary school, three years at high school and taken further English course at university. The samples are 337 students from 13 faculties which taken using stratified random sampling technique. 


\subsection{Instrument}

The six-section of questionnaire was designed with 13 questions in the close-ended format. The first section elicited background information. The second section entailed the frequency of ICT use for general and English learning purposes. The third section elicited for what purposes do the students use ICT for general purpose. The fourth section elicited for what purposes do the students use ICT for English learning purpose. The fifth section dealt with the students' perception towards ICT use for English language learning. The last section dealt with the students' expectation towards ICT use for English language learning.

Before the instrument was administered in the study, piloting was conducted to representative group who were not included in the main study in order to enable the researcher to identify and modify the instrument to make sure its validity and reliability. The instrument also was translated into Indonesian language to ensure the participants' comprehension of the instrument.

\subsection{Data Analysis Procedures}

The data were analyzed quantitatively. The responses of participants were analyzed using SPSS version 23. Descriptive statistics were performed in order to find out the frequencies and percentages of ICT use both general purposes and English learning purposes. The result was taken into consideration to draw conclusion on students' perception and students' expectation towards ICT use for English language learning.

In analyzing the data, researcher used descriptive statistics in which custom tables in SPSS program in order to get the frequency and percentage of each variable. Then the data were displayed in form of figure and table to make statistical interpretation. The test results showed the percentages and frequencies, and are presented in the charts and tables in the following section.

\section{Findings}

\subsection{Demographic Profile and ICT Devices Ownership}

This figure showed the respondents' gender, it is between male and female.

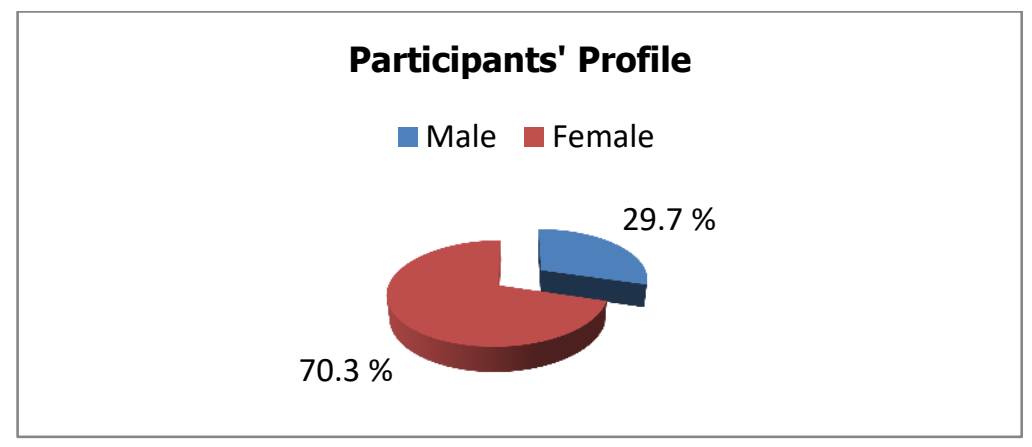

Figure 1. Gender Profile of Respondents

Figure 1 above, showed the demographic profile of respondents. Based on the total of respondents (337 respondents), it can be seen that the majority $70.3 \%$ (237 respondents) are female, and $29.7 \%$ (100 respondents) are male. 


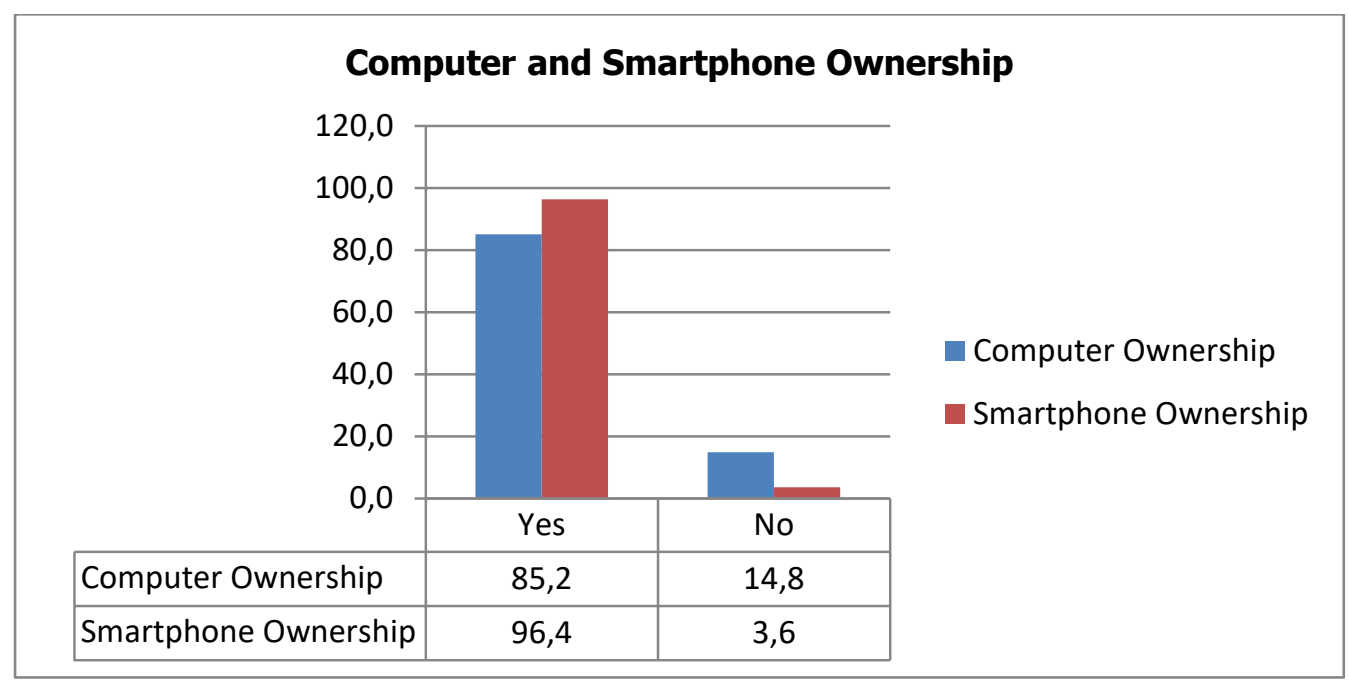

Figure 2. Computer and Smartphone Ownership

Figure 2 above, displayed the computer and smartphone ownership that owned by the respondents. It showed the overwhelming majority of respondents have computer and smartphone $85.2 \%$ (287 respondents) and 96.4\% (325 respondents) respectively. Only a small number of respondents who did not have computer and smartphone. The respondents who did not have computer only $14.8 \%$ (50 respondents), and who did not have smartphone only $3.6 \%$ (12 respondents).

\subsection{Frequency of ICT Use a Day for General Purposes and English Learning Purposes}

This figure shows that The ICT use frequency both for general purposes and for English language learning purposes.

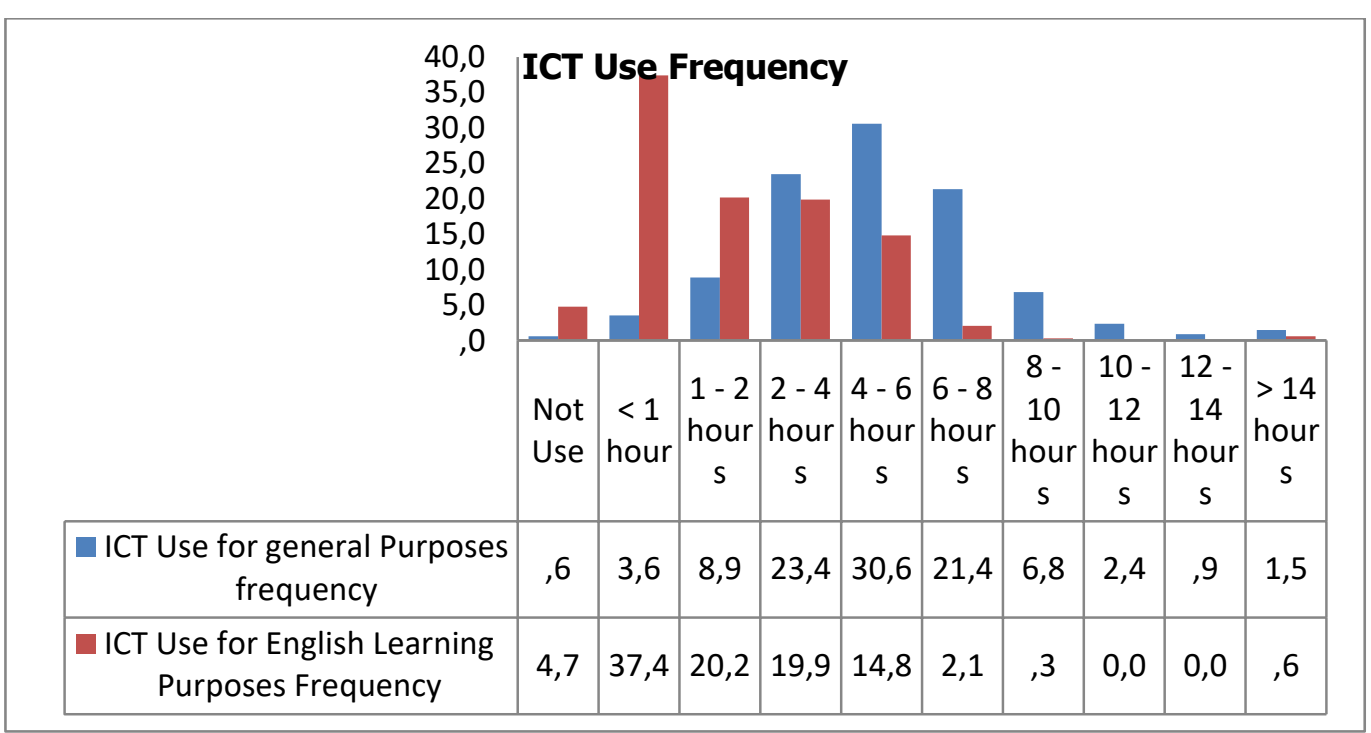

Figure 3. Percentages of ICT Use Frequencies

The first question is the frequency of ICT use for general purposes and English learning purposes, it was displayed on figure 3. In the frequency of ICT use for general purposes (nonlearning purposes), $30.6 \%$ of respondents claimed that they spent $4-6$ hours in a day using ICT for general purposes (non-learning purposes). 23.4\% of respondents reported that they spent 2 4 hours, $21.4 \%$ spent $6-8$ hours, $8.9 \%$ spent $1-2$ hours, $6.8 \%$ spent $8-10$ hours in a day for 
non-learning purposes. Only a small number who used ICT for general purposes from $12-14$ hours and more than 14 hours a day, it is approximately $0.9 \%$ and $1.5 \%$ respectively.

The frequency of ICT use for English language learning purposes can be seen at figure 3 above. Many respondents (37.4\%) claimed that they spent below 1 hour a day to use ICT for English language learning purposes. The next, $20.2 \%$ of respondents reported that they spent $1-2$ hours a day, $19.9 \%$ spent $2-4$ hours, and $4.7 \%$ of respondents claimed that they did not use ICT for English language learning purposes. It needs to be examined further that $4.7 \%$ of respondents did not use ICT for English learning, whether they did not know how to utilize ICT to learn English, or they were not interested in learning English using ICT, or even they used more ICT for general purposes than English learning.

\subsection{Activities of ICT Use for General Purposes}

This figure shows the activities of ICT use for general purposes by the students. There are several categories, namely checking email, using social media, reding online news, downloading or listening to the music, watching Youtube, googling, using google map, playing games, online shopping, and others.

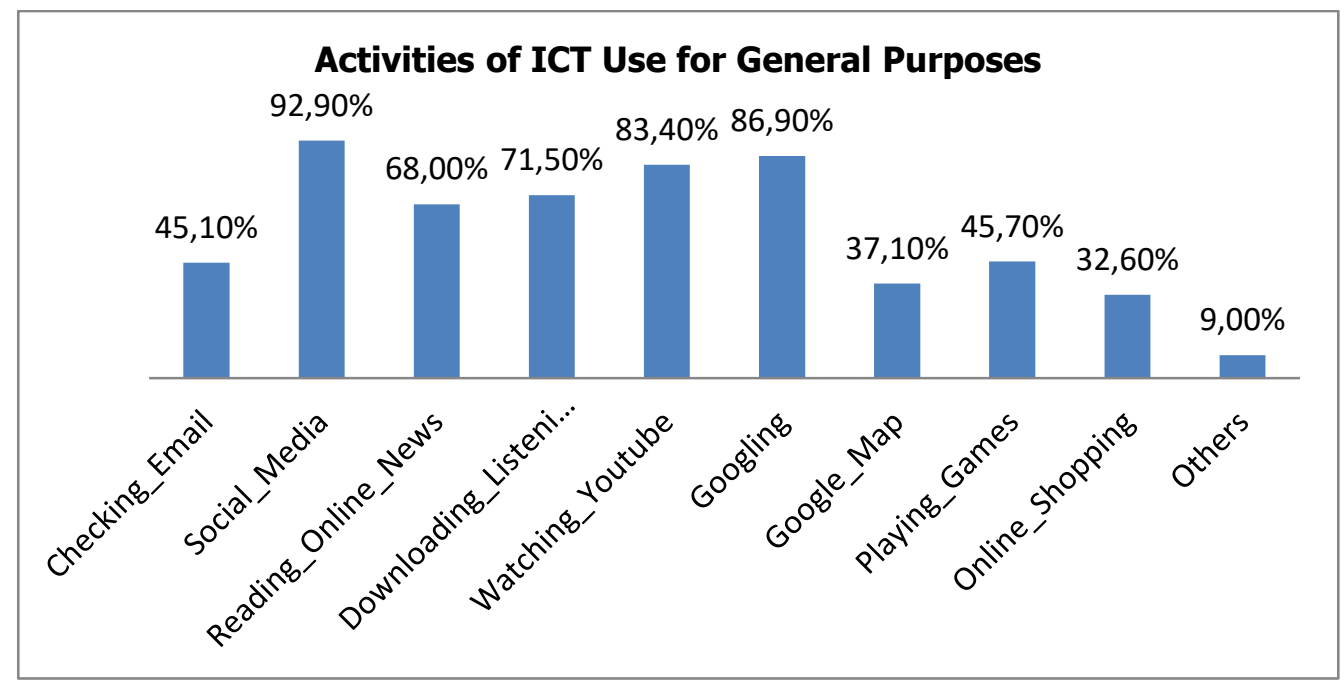

Figure 4. Activities of ICT Use for General Purposes

The second research question concerned about the activities of using ICT for general purposes. Figure 4 showed the third most frequent activities of ICT use for non-learning purposes that are; using social media, using Google, and using Youtube (92.9\%, 86.9\% and $83.4 \%$ respectively). Then followed by downloading or listening to the music (71.5\%), reading online news (68\%), playing games $(45.7 \%)$, and checking email (45.1\%). The respondents also reported that they used ICT for using Google map (37.1\%), online shopping (32.6\%), and others 9\% (using online transportation, reading, downloading film/application, making video content, Webtoon, marathon anime, and trading).

\subsection{Activities of ICT Use for English Learning Purposes}

This figure shows the activities of ICT use for English language learning purposes by the students. There are several categories, namely using dictionary, google translation, searching online materials, listening practice, reading practice, speaking practice, writing practice, learning vocabulary, learning grammar, pronunciation practice, discussing assignment, using online 
English learning forum, using English learning software, using English learning game, and others.

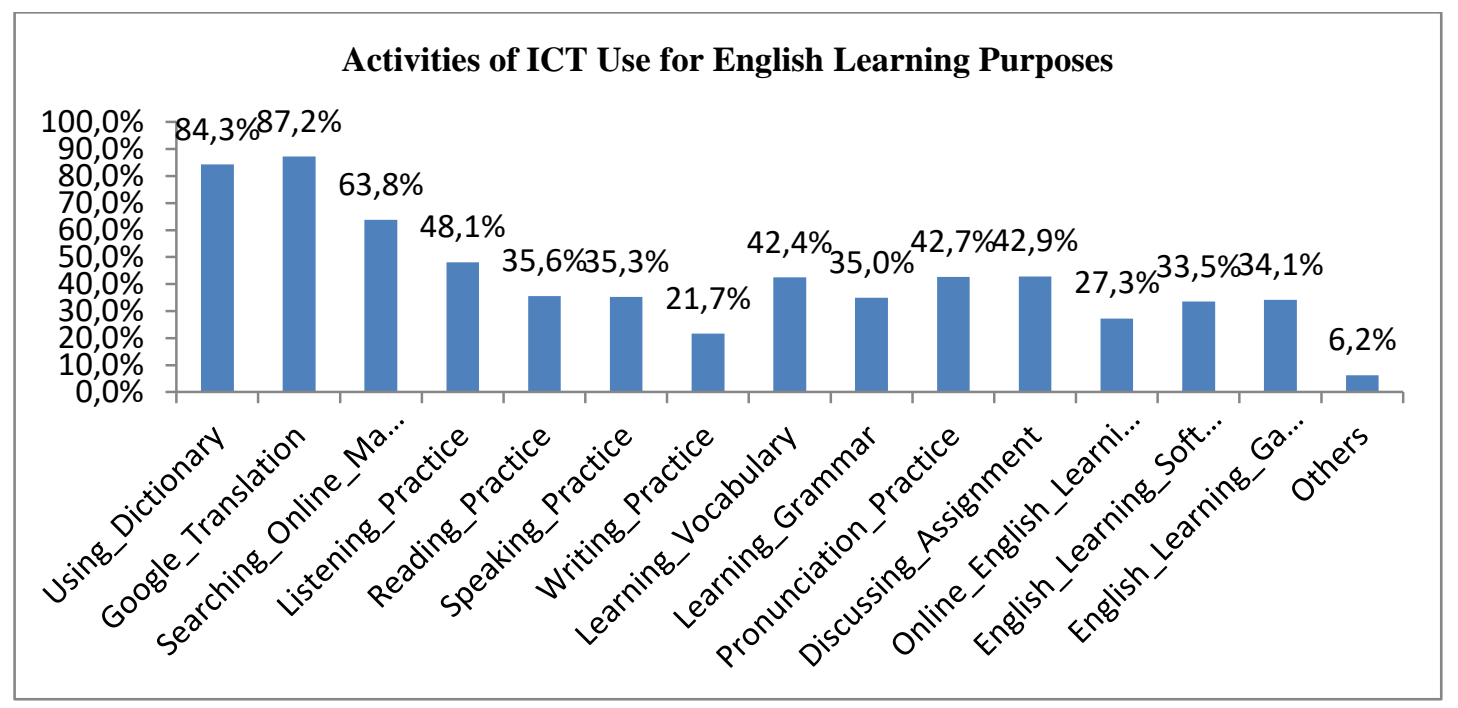

Figure 5. Activities of ICT Use for English learning Purposes

The third research question is the activities of learners using ICT for English language learning. Figure 5 reflects that Google translation is the most frequent activity that the learners use for English language learning (87.2\%). Followed by using dictionary and searching online materials, $84.3 \%$ and $63.8 \%$ respectively. In terms of language skills (listening, reading, speaking, and writing), many students claimed that they used ICT for listening practice $(48.1 \%)$, followed by reading practice $(35.6 \%)$, speaking practice (35.3\%), and writing practice $(21.7 \%)$.

In addition, an astonishing findings that no more than half of the students using ICT for learning vocabulary, grammar, nor pronunciation practice $(42.4 \%, 35 \%$, and $42.7 \%$ respectively). The last, students reported that they used ICT for English learning game (34.1\%), English learning software (33.5\%), and join online English learning forum (27.3\%).

\subsection{Students' Perception towards ICT Use for English Language Learning}

This table indicated the students' perception towards ICT use in English language learning. There are some several questions including the effectiveness if ICT use, improving English language skills, improving grammar competence, enhance vocabulary, acquire pronunciation, makes ELL enjoyable, easy to understand, easy to discuss about materials, easy to find sources of material, and easy to access.

Table 1. Students' Perception towards ICT use in English Language Learning

\begin{tabular}{|l|c|c|}
\hline \multicolumn{1}{|c|}{ Items } & Frequency & Percentage \% \\
\hline The use of ICT helps me to learn English effectively & 287 & $85.20 \%$ \\
\hline The use of ICT helps me to improve listening skill & 195 & $57.90 \%$ \\
\hline The use of ICT helps me to improve reading skill & 128 & $38.10 \%$ \\
\hline The use of ICT helps me to improve speaking skill & 164 & $48.70 \%$ \\
\hline The use of ICT helps me to improve writing skill & 104 & $30.90 \%$ \\
\hline The use of ICT helps me to acquire grammar competence & 122 & $36.30 \%$ \\
\hline The use of ICT helps me to enhance vocabularies & 179 & $53.30 \%$ \\
\hline
\end{tabular}




\begin{tabular}{|l|c|c|} 
The use of ICT helps me to acquire pronunciation & 170 & $50.40 \%$ \\
\hline The use of ICT makes English learning more enjoyable & 226 & $67.10 \%$ \\
\hline The use of ICT makes understanding English learning material easier & 194 & $58.10 \%$ \\
\hline $\begin{array}{l}\text { The use of ICT makes it easy to find and get English language learning } \\
\text { materials }\end{array}$ & 225 & $66.80 \%$ \\
\hline The use of ICT is a good way for lecturers to deliver learning materials & 148 & $43.90 \%$ \\
\hline $\begin{array}{l}\text { The use of ICT is a good way for students and lecturers to communicate, } \\
\text { share, and discuss about materials and assignments }\end{array}$ & 157 & $46.70 \%$ \\
\hline Lecturers have used ICT in English learning process & 165 & $49.10 \%$ \\
\hline $\begin{array}{l}\text { Lecturers have provided learning materials that can be accessed or used } \\
\text { outside the classroom }\end{array}$ & 114 & $34.00 \%$ \\
\hline $\begin{array}{l}\text { Lecturers have provided opportunities for students to communicate, share, } \\
\text { and discuss through ICT outside the classroom }\end{array}$ & 107 & $31.80 \%$ \\
\hline It is easy for students to access the internet on campus & 102 & $30.30 \%$ \\
\hline $\begin{array}{l}\text { I am satisfied with the ICT facilities provided by the campus for the learning } \\
\text { process }\end{array}$ & 70 & $20.80 \%$ \\
\hline I am used to using ICT to learn learning materials at home & 119 & $35.30 \%$ \\
\hline The use of ICT does not help me to master English proficiency & 6 & $1.80 \%$ \\
\hline The use of ICT does not make learning English effective & 5 & $1.50 \%$ \\
\hline Others & 0 & $0.00 \%$ \\
\hline
\end{tabular}

The fourth research question asked about students' perception towards the use of ICT for English language learning. The majority of students (85.2\%) perceived that the use of ICT makes them to learn English effectively. In terms of The use of ICT makes English learning more enjoyable, the students claimed agree to this statement $(67.1 \%)$. Then, $66.8 \%$ of respondents perceived that the use of ICT makes it easy to find and get English language learning materials. In addition, more than half of respondents expressed positive responses to the following statements; The use of ICT makes understanding English learning material easier (58.1\%), The use of ICT helps me to improve listening skill (57.9\%), The use of ICT helps me to enhance vocabularies (53.3\%), The use of ICT helps me to acquire pronunciation (50.4\%).

\subsection{Students' Expectation towards ICT Use for English Language Learning}

This table indicated the students' expectation towards ICT use in English language learning. There are some several questions including the effectiveness if ICT use, improving English language skills, the use of ICT by the lecturers, easy to access, and improving English fluency.

Table 2. Students' Expectation towards ICT use in English Language Learning

\begin{tabular}{|l|c|c|}
\hline \multicolumn{1}{|c|}{ Items } & Frequency & Percentage \% \\
\hline I hope that the use of ICT allows me to learn English more effective & 276 & $81.90 \%$ \\
\hline $\begin{array}{l}\text { I hope ICT is used more frequently in learning process to help me improve my } \\
\text { English language skills }\end{array}$ & 249 & $73.90 \%$ \\
\hline Lecturers need to use ICT in learning English to students & 189 & $56.10 \%$ \\
\hline $\begin{array}{l}\text { I would like lecturers to deliver authentic materials and updated materials through } \\
\text { ICT in English learning }\end{array}$ & 164 & $48.80 \%$ \\
\hline
\end{tabular}




\begin{tabular}{|l|c|c|}
\hline I hope the lecturer informs how to find and use online English learning resources & 198 & $58.80 \%$ \\
\hline $\begin{array}{l}\text { I hope ICT is used more frequently in learning process to make English learning } \\
\text { more enjoyable }\end{array}$ & 208 & $61.70 \%$ \\
\hline $\begin{array}{l}\text { Lecturers need to provide learning materials that can be accessed / used outside } \\
\text { the classroom }\end{array}$ & 185 & $54.90 \%$ \\
\hline $\begin{array}{l}\text { I would like to keep communicating and discussing about learning materials with } \\
\text { lecturers through ICT after class ends }\end{array}$ & 162 & $48.10 \%$ \\
\hline I hope to join an online English learning forum to improve my English proficiency & 149 & $44.20 \%$ \\
\hline $\begin{array}{l}\text { I would like campus to provide ICT facilities that can be used for the learning } \\
\text { process }\end{array}$ & 205 & $60.80 \%$ \\
\hline $\begin{array}{l}\text { I hope campus to provide the better internet access that students can use in } \\
\text { learning }\end{array}$ & 211 & $62.60 \%$ \\
\hline I don't want lecturers to use many ICT applications in English learning process & 17 & $5.00 \%$ \\
\hline I don't want to learn English through ICT & 1 & $0.30 \%$ \\
\hline Others & 0 & $0.00 \%$ \\
\hline
\end{tabular}

The last research question asked about the students' expectation towards the use of ICT for English language learning. Table 2 above indicates that most of the respondents expected that the use of ICT allows them to learn English more effective (81.9\%), and the ICT is used more frequently in learning process to improve English language skills (73.9\%). Some interesting findings were that the students want better internet access on campus, and they expected that campus can provide better ICT facilities to use in learning process $(62.6 \%$ and $60.8 \%$ respectively).

In addition, $61.7 \%$ of respondents expressed that they hoped ICT is used more frequently in learning process to make English learning more enjoyable. Furthermore, they expected that the lecturer inform them how to find and use online English learning resources (58.8\%), and the lecturer need to provide learning materials that can be accessed and used outside the classroom (54.9\%).

\section{Discussion}

The findings in this study revealed that the students spent more time per day using ICT for general purposes (non-learning purposes) than for English learning purposes. Specifically, 63.6\% of them spent more than 4 hours per day using ICT for general purposes while only $17.8 \%$ of them spent more than 4 hours per day for English language learning purposes. The findings support previous research that showed that majority of respondents spent more time using ICT for general purposes than for learning English (Melor, Maimun, \& Chua, 2009).

From the findings about students' activities of using ICT for general purposes, the majority of the students using social media 92.9\%, using Google 86.9\%, and using Youtube $83.4 \%$. It means that the students spent more time for general purposes such as surfing the internet for pleasure, using social media, using Youtube, listening to the music, and playing games. Based on the data of students' activities using ICT for English learning purposes, Google translation is the most 
frequent activity that the learners use for English language learning (87.2\%). Then, followed by using dictionary and searching online materials, $84.3 \%$ and $63.8 \%$ respectively.

According to the finding of students' perception, the majority students perceive that the use of ICT makes them to learn English effectively (85.2\%). 67.1\% students agrees that the use of ICT makes English learning more enjoyable, then $66.8 \%$ of respondents perceived that the use of ICT makes it easy to find and get English language learning materials. In addition, more than half of respondents expressed positive responses towards the use of ICT makes understanding English learning material easier (58.1\%).

It can be concluded that the use of ICT can improve the students' English language skills (Oktalia et al., 2018). They also perceive that ELL can be more enjoyable when the teacher used ICT in teaching and learning process. The students also have positive attitude towards the use of ICT in English language learning (Sabti \& Chaichan, 2014; Tri \& Nguyen, 2014).

This study also indicated that most of the respondents (81.9\%) expected that ICT allows them to learn English language more effective, and $73.9 \%$ expressed that the ICT is used more frequently in learning process to improve their English language skills (Habibi et al., 2018). More than half of respondents showed that they want better internet access on campus $(62.6 \%)$, and they expected that campus can provide better ICT facilities to use in learning process $(60.8 \%)$. Furthermore, $61.7 \%$ of respondents expected that they hoped ICT is used more frequently in learning process to make English learning more enjoyable.

Based on the findings on students' expectation it can be concluded that the students expected that ICT can make English language learning more enjoyable and effective. The use of ICT by the teachers in ELL can be more frequently in order to improve students' English language skills (Alfarwan, 2019). And the last, the students expected that campus can provide better ICT facilities so that the students can take advantages of ICT in English language learning.

\section{Conclusion}

To sum up, the majority of the students spent more time using ICT for general purposes (nonlearning purposes) such as using social media, watching Youtube, listening to the music, surfing the internet, and playing games than for English language learning purposes. while google translation, using dictionary, and searching online materials are common and frequently used by the students. On the other hand, they reflected positive perception towards the use of ICT in English language learning. They expected that the use of ICT makes them to learn English more effective. They also perceive that ICT utilization makes English learning more enjoyable.

Students expected that ICT used more frequently in English language learning process to improve their English language skills. Majority of the students stated that ICT facilities were available in campus, and they expected that campus can provide the better facilities of ICT that they can use in teaching and learning process. More than half of students also stated that internet access is available in campus but they expressed that they need better internet access in campus. 


\section{References}

Alfarwan, S. (2019). University student access to and use of electronic devices: A latent English language learning potential. Teaching English with Technology, 19(1), 102-117. Retrieved from http://cejsh.icm.edu.pl/cejsh/element/bwmeta1.element.desklight-464a8909-433348ea-a1d8-cbb571df950e

Anas, I., \& Musdariah, A. (2018). Being an E-Teacher: Preparing the ESL Teacher to Teach English with Technology. Journal of English Language Teaching and Linguistics, 3(1), 4156.

Annamalai, N. (2017). Exploring Students Use of Facebook in Formal Learning Contexts. Indonesian Journal of EFL and Linguistics, 2(2), 91-106.

Benghalem, B. (2015). The effects of using microsoft power point on EFL learners' attitude and anxiety. Advances in Language and Literary Studies, 6(6), 1-6. https://doi.org/10.7575/aiac.alls.v.6n.6p.1

Boutonglang, D., \& Flores, F. (2011). A study on integrating technology to engage 7 th graders into an English as a foreign language (EFL) classroom in a rural secondary school, Thailand. International Journal of Arts \& Sciences, 4(18), 195-206.

Chouit, D., Abdelhamid, N., \& Laabidi, H. (2017). Exploring the Correlation between Professors ' Use of ICT in Teaching and the Levels of Institutional Support. Journal of English Language Teaching and Linguistics, 2(1), 47-63.

Dalton, M. L. (2011). Social Networking and Second Language Acquisition: Exploiting SkypeTM Chat for the Purpose of Investigating Interaction in L2 English Learning (Iowa State University, The USA). Retrieved from http://lib.dr.iastate.edu/etd/10221/

Davies, G., \& Hewer, S. (2009). Introduction to New Technologies and How They Can Contribute to Language Learning and Teaching. Module 1.1. in G Davies (Ed.), Information and Communication Technology for Language Teachers (ICT4LT). Slough: Thames Valley University.

Fatiha, M., Sliman, B., Mustapha, B., \& Yahia, M. (2014). Attitudes and motivations in learning English as a foreign language. International Journal of Arts \& Sciences, 07(03), 117-128.

Fauzan, U., \& Pimada, L. humairo. (2018). ICT-Based Teaching of English at Madrasah Aliyah in Kalimantan. Journal of Education in Muslim Society, 5(2), 193-211.

Foti, M. K., \& Mendez, J. (2014). Mobile learning: How students use mobile devices to support learning. Journal of Literacy and Technology, 15(3), 58-78.

Habibi, A., Mukminin, A., Riyanto, Y., Prasojo, L. D., Sulistiyo, U., Sofwan, M., \& Saudagar, F. (2018). Building an online community: Student teachers' perceptions on the advantages of using social networking services in a teacher education program. Turkish Online Journal of Distance Education, 19(1), 46-61.

Harris, L. (2011). Secondary teacher's conception of students engagement: Engagement in learning or in schooling? Teaching and Teacher Education, 27(2), 376-386.

Idowu, S. O., \& Gbadebo, A. D. (2017). Extent of utilization of information and communication technology tools by English language teachers in Ijebu-Ode and Odogbolu local government areas of Ogun State, Nigeria. International Journal of Arts \& Sciences, 09(04), 589-596.

Ilter, B. G. (2009). Effect of technology on motivation in EFL classrooms. Turkish Online Journal of Distance Education, 10(4), 136-158.

Johri, A., Teo, H. J., Lo, J., Dufour, M., \& Schram, A. (2014). Milenial enginers: Digital media 
and information ecology of engineering students. Computers in Human Behavior, 33(3), 286-301.

Kennewell, S. (2004). Meeting the Standards in Using ICT for Secondary Teaching. London: Routledge.

Khaloufi, A., \& Laabidi, H. (2017). An Examination of the Impact of Computer Skills on the Effective Use of ICT in the Classroom. Indonesian Journal of EFL and Linguistics, 2(1), 5369.

Kramsch, C., \& Thorne, S. L. (2002). Foreign Language Learning as Global Communicative Practice. In D. Block and D. Cameron (Eds), Globalization and Language Teaching. New York: Routledge.

Krista, G., \& Jay, B. (2001). English in the digital age: Information and communications technology and the teaching of English. Journal of Adolescent \& Adult Literacy, 44(4), 388390.

Manakil, J., \& George, R. (2017). Mobile learning practices and preferences a way forward in enhancing dental education learning experience. 22-28. https://doi.org/10.4103/22789626.198603

Meleisea, E. (2007). The UNESCO ICT in Education Program. Bangkok, Thailand: United Nations, Education, Scientific, and Cultural Organization.

Melor, M. Y., Maimun, A. L., \& Chua, P. L. (2009). Language learning via ICTs: uses, chalenges and issues. WSEAS Transactions on Information Science and Aplication, 9(6), 1453-1467.

Murray, D. E. (2005). Technologies for second language literacy. Annual Review of Applied Linguistics, 25(1), 188-201.

Oktalia, D., Ngadiso, \& Supriyadi, S. (2018). Integrating ICT in English language learning: Students ' perceptions of a state university in Jambi Province. International Journal of Language Teaching and Education, 2(1), 49-59.

Sabti, A. A., \& Chaichan, R. S. (2014). Saudi high school students' attitudes and barriers toward the use of computer technologies in learning English. SpringerPlus, 3(1), 1-9. https://doi.org/10.1186/2193-1801-3-460

Shevchenko, M. V. (2018). The role of authentic videos in teaching English at technical universities. Advanced Education, 2015(4), 66-70. https://doi.org/10.20535/24108286.57306

Tri, D. H., \& Nguyen, N. H. T. (2014). An exploratory study of ICT use in English language learning among EFL university students. Teaching English with Technology, 14(4), 32-46.

Vaughan, D. (2011). The importance of capabilities in the sustainability of information and communications technology programs: The case of remote Indigenous Australian communities. Ethics and Information Technology, 13(2), 131-150. https://doi.org/10.1007/s10676-011-9269-3

Zhang, H., Song, W., \& Burston, J. (2011). Re-examining the effectiveness of vocabulary learning via mobile phones. Turkish Online Journal of Educational Technology, 10(3), 203-214. 